\title{
Fructan and its relationship to abiotic stress tolerance in plants
}

\author{
David P. Livingston III · Dirk K. Hincha · \\ Arnd G. Heyer
}

Received: 14 January 2009/Accepted: 4 February 2009/Published online: 17 March 2009

(C) The Author(s) 2009. This article is published with open access at Springerlink.com

\begin{abstract}
Numerous studies have been published that attempted to correlate fructan concentrations with freezing and drought tolerance. Studies investigating the effect of fructan on liposomes indicated that a direct interaction between membranes and fructan was possible. This new area of research began to move fructan and its association with stress beyond mere correlation by confirming that fructan has the capacity to stabilize membranes during drying by inserting at least part of the polysaccharide into the lipid headgroup region of the membrane. This helps prevent leakage when water is removed from the system either during freezing or drought. When plants were transformed with the ability to synthesize fructan, a concomitant increase in drought and/or freezing tolerance was confirmed. These experiments indicate that besides an indirect effect of supplying tissues with hexose sugars, fructan has a direct protective effect that can be demonstrated by both model systems and genetic transformation.
\end{abstract}

Keywords Inulin - Levan - Cold acclimation ·

Subzero acclimation · Model systems · Liposomes ·

Membrane stabilization - Sugar glasses ·

Lipid phase transitions - Plant transformation

D. P. Livingston III ( $\square)$

USDA and North Carolina State University, 840 Method Road,

Unit 3, Raleigh, NC 27695, USA

e-mail: dpl@unity.ncsu.edu

D. K. Hincha

Max-Planck-Institut für Molekulare Pflanzenphysiologie,

Am Mühlenberg 1, 14476 Potsdam, Germany

A. G. Heyer

Biologisches Institut, Abt. Botanik, Universität Stuttgart, Pfaffenwaldring 57, 70569 Stuttgart, Germany

\section{Introduction}

Sucrose and starch are the primary vegetative storage carbohydrates in tropical and subtropical grasses, while temperate and cool zone grasses mainly accumulate fructose polymers called fructans [1]. From 12 to $15 \%$ of angiosperms reportedly contain fructan [2]. They are produced in monocots as well as dicots [3] and are distributed in stems, leaves, inflorescences, and seeds [4]. While fructan is considered a short-term storage carbohydrate, it has been implicated for many years in stress-tolerance mechanisms in plants. In this review, a brief description of fructan and the enzymes involved in its synthesis and hydrolysis will be followed by a focused review of research investigating the role of fructan in minimizing the effect of abiotic stress on plant tissue.

\section{Structure}

Five types of fructan (Table 1), distinguished by glycosidic linkages, have been described [5]: (1) Inulin, which occurs, e.g., in chicory and Jerusalem artichoke, has 2-1 linkages between its fructosyl residues. The shortest form of inulin is the trisaccharide 1-kestose (Fig. 1) (See Roberfroid [6] for a comprehensive review of inulin). (2) Levan (or phlein) is the principal monocot fructan and consists of 2-6 linked fructosyl units in a linear arrangement. (3) Branched (graminin) fructans have been reported in wheat [7] and have either a levan or inulin backbone with one or more short branches. (4) Inulin neoseries are linear with 2-1 linkages but with the glucose molecule between two fructosyl subunits. This type of fructan has been identified in onion and asparagus [8]. (5) Levan neoseries has been reported in oat and Lolium $[9,10]$ and is based on 6G kestotriose (neokestose). This 
Table 1 Five types of fructan in plants showing a representative plant species in which the respective type of fructan has been identified

\begin{tabular}{llll}
\hline Type & Representative species & Linkage $(\beta)$ & Initial trisaccharide \\
\hline Inulin & Chicory, Jerusalem artichoke & $2-1$ & $1-$ kestose \\
Levan & Dactylis glomerata & $2-6$ & $6-k e s t o s e$ \\
Branched & Wheat, barley & $2-1$ and 2-6 & $1-$ and 6-kestose \\
Inulin neoseries & Onion, asparagus, Lolium & $2-1$ & $6 \mathrm{G}-\mathrm{kestotriose}$ (neokestose) \\
Levan neoseries & Lolium, oats & $2-6$ & $6 \mathrm{G}-\mathrm{kestotriose}$ (neokestose) \\
\hline
\end{tabular}
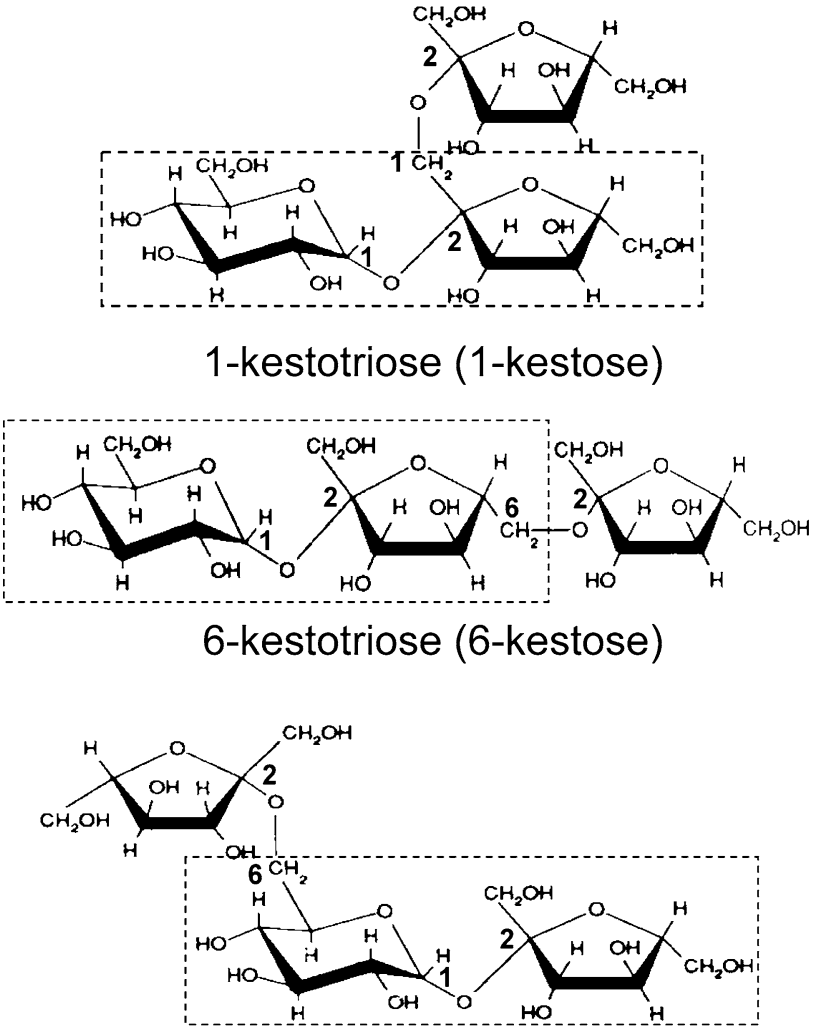

\section{$6_{\mathrm{G}}$-kestotriose (neokestose)}

Fig. 1 The structure of the initial trisaccharides of fructan listed in Table 1 . The system used to name fructan is described by Waterhouse and Chatterton [11]. The boxes show the sucrose moiety in each molecule. The linkage between monomers is indicated by numbers adjacent to the respective carbon atoms

fructan has an internal glucose molecule as in (4) but the linkages are 2-6 [11].

\section{Biosynthesis}

Fructan synthesis is initiated when photosynthesis exceeds demand, reportedly when sucrose levels in sink organs reach a critical level [12]. Synthesis is complex due to differences between species in linkages, branching patterns, and sizes; however, a model for synthesis in plants that includes four fructosyltransferases has been proposed [5] (Fig. 2).

Synthesis reportedly begins in the vacuole with sucrose as both the donor and substrate. The first transferase enzyme, sucrose-sucrose fructosyltransferase (1-SST), forms 1-kestose (Fig. 1) from two sucrose molecules (releasing a glucose). An elongating enzyme, fructanfructan fructosyltransferase (1-FFT), transfers a single terminal fructose residue from an oligosaccharide to the same carbon position on another molecule, thus producing the fructan inulin.

1-SST and 1-FFT were first described by Edelman and Jefford [13] and Darbyshire and Henry [14] and were cloned by Hellwege et al. $[15,16]$ and Van der Meer et al. [17]. In barley and wheat the enzyme sucrose:fructan 6fructosyltransferase (6-SFT) was cloned by Sprenger et al. [18]. This enzyme is capable of producing 6-kestose as well as elongating 6-kestose and 1-kestose and producing both levan (Table 1) and branched fructans.

An enzyme capable of synthesizing 6G-kestose (neokestose) in onion was first described by Shiomi [8] and was cloned by Vijn et al. [19]. A third elongating enzyme (6GFFT) that causes elongation of 6G-kestose and produces the inulin neoseries in Lolium was identified by St. John et al. [20].

Researchers have been cautioned that fructan synthesis may be more complex than shown in the model [5] because different fructosyltransferase enzymes have been found to synthesize several different fructan molecules depending on substrate availability or incubation conditions. In addition, sucrose may not be the only substrate for fructan synthesis since fructan molecules without a glucose residue have been reported [21]. Another complication is that acid invertases are highly homologous to fructosyltransferases, and the role these and other invertases might play in fructan synthesis [22] is unclear.

Environmental factors, affecting growth rates, have a significant influence on fructan accumulation. Grasses can store large quantities during slow growth periods, when assimilate production exceeds demand. This typically occurs in the fall with low temperatures and continuing photosynthesis [12, 23, 24]. Fructan accumulation for four different grasses was highest between November and January [25]. 
Fig. 2 Proposed model for fructan synthesis. Adapted from [5]. See text for explanation

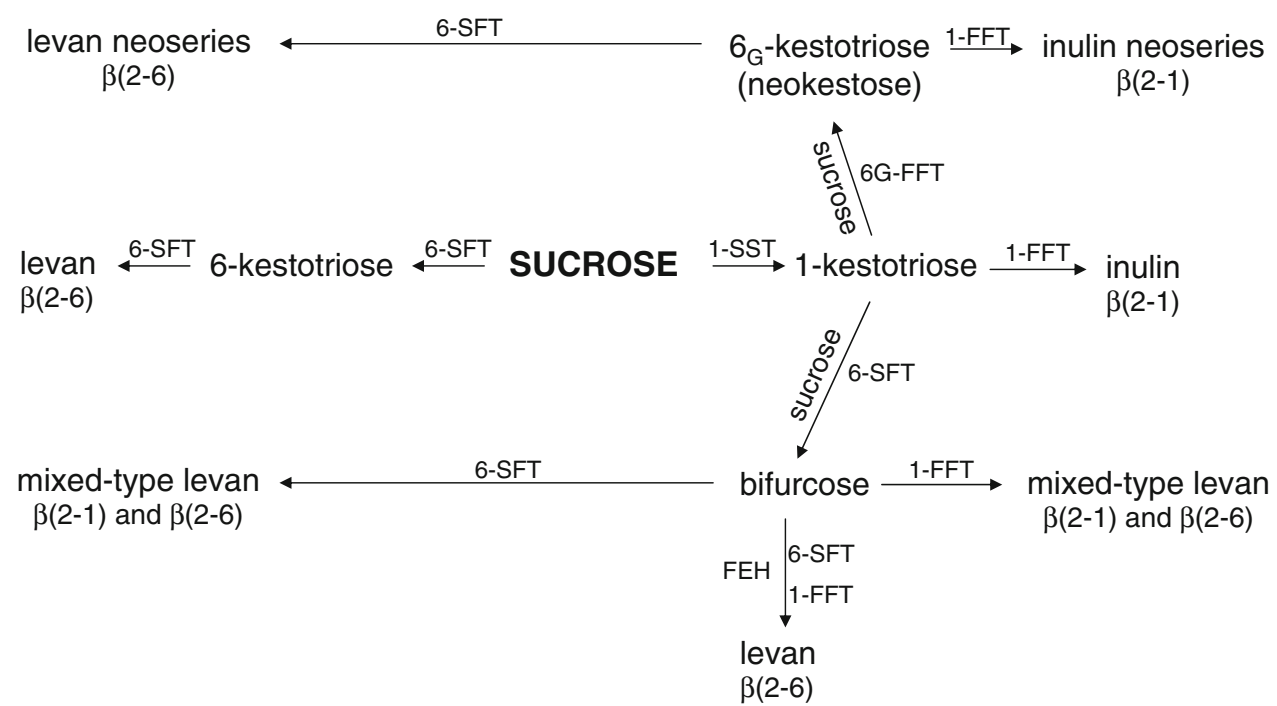

Nutrient availability also affects fructan accumulation. Archibold [23] found an inverse relationship of nitrogen and phosphorus levels to fructan amounts in barley and a positive relationship of potassium to fructan. Besides confirming the inverse nitrogen relationship, Westhafer [26] demonstrated that fructan was the most responsive carbohydrate to nitrogen levels in Kentucky bluegrass stems.

Chatterton et al. [27] reported a range for fructan of 0 up to $45 \%$ of dry weight in an analysis of carbohydrates (including fructan) from leaves of 185 genotypes of Gramineae. In that study, fructan accumulated only in coolseason grasses and not in warm-season species. Other researchers reported that during environmental conditions that favored accumulation, fructan accounted for as much as $80 \%$ of dry weight $[13,28]$. Concentrations as high as $90 \%$ were reported by Meier and Reid [4].

Fructan has been found to accumulate in various tissues during periods when light levels promoted carbon fixation while lower temperatures reduced growth [23, 24, 29-31]. Edelman and Jefford [13] suggested that fructan accumulated in the vacuole and provided a sink within the cell that allowed photosynthesis to continue. Vacuolar compartmentation of fructan was confirmed by Wagner et al. [32] in barley and helped explain high fructan concentrations under conditions where low temperatures reduced growth rates while photosynthesis continued (see reviews [30, $33,34])$.

\section{Mobilization}

Mobilization of fructan reserves usually begins when active growth starts through exolytic hydrolysis with fructan exohydrolases (FEH). Several FEHs have been characterized and cloned. There are FEHs that hydrolyze the 2-1 linkages of inulin (1-FEH) [35], 6-FEHs that preferentially hydrolze 2-6 linkages [36, 37] as well as those that hydrolyze both 2-1 and 2-6 linkages [38]. In addition, FEHs that hydrolyze fructan based on 6-kestotriose have also been described [39]. An FEH has recently been cloned from Lolium that may be involved in fructan synthesis by acting as a trimming enzyme [40].

FEHs are closely related to cell-wall invertases [41]. The rice genome encodes two vacuolar invertases with fructan exohydrolase activity but lacks the related fructan biosynthesis genes of the Pooideae [42]. In some species, sucrose is an inhibitor of FEH activity suggesting that it may be a feedback inhibitor in the hydrolysis of fructan during mobilization [43].

\section{Role of fructan in abiotic stress resistance}

Fructan accumulation during periods of reduced growth under low but nonfreezing conditions (cold acclimation) has frequently been correlated with an increase in freezing tolerance [24, 44-46]. This correlation stimulated research to explain how fructan might be involved in protection from freezing stress. In addition, because desiccation is an important component of freezing stress [47-49], studies investigating the possibility that fructan may be involved in alleviation of drought stress were also initiated. Advantages of fructan accumulation over that of starch as a protectant in abiotic stress are (1) fructan's high water solubility, (2) the resistance of fructan to membrane-damaging crystallization at subzero temperatures, and (3) the ability of the synthesis pathway of fructan to function normally even at low temperatures [5, 45]. 
Fructan as a source of hexose sugars

The demonstration that simple sugars can protect plants from freezing injury [50-53] led to the speculation that fructan may act as a source of hexose sugars that would protect tissues by reducing the freezing point of plant liquid [46, 54]. Johanssen [55] followed the freezing point of wheat at different solute concentrations and found that the temperature at which leaf tissues froze was lowered on a "purely colligative basis". While this seems to support the hypothesis that the role of fructan in cryoprotection is to provide simple sugars, it has been observed that even if most of the fructan in oat were hydrolyzed, the increased hexose sugars would only lower the freezing point of water by a fraction of a degree [56, 57]. In fact, the highest recorded vegetative plant cell-sap concentration would lower the freezing point by only $4^{\circ} \mathrm{C}$ [47].

These observations caused some authors to question whether a relationship between sugars and protection from freezing existed at all $[57,58]$. Contributing to the uncertainty of the role of sugars in cryoprotection was the fact that most studies correlating sugars with freezing tolerance measured sugars in whole plants or major plant organs such as leaves, roots, or crowns. However, it has been shown that plant death from freezing is a result of the death of specific regions of plants and even specific cells [59-66]. Canny [67] demonstrated that sugars are concentrated in specific regions of plants called "sumps". These regions of high sugar concentrations could reduce the freezing point in those locations significantly beyond the $4^{\circ} \mathrm{C}$ cited by Levitt [47]. If higher concentrations of sugar were within regions of the plant crucial for whole-plant survival, then while freezing-point depression would certainly not be the only protective mechanism, it could be a significant means by which plants survive abiotic stress.

Cell plasmolysis is an additional negative effect on plants induced by freezing and drought that sugars may help prevent. Williams [68] found a minimum volume to which cells were reduced before being killed by determining kill temperatures of shrinking cells in solutions of different solute concentration (see [47] for a detailed review of frost plasmolysis). Freezing damage to individual cells is the combined result of many injuries (e.g., oxidative damage, membrane phase changes, membrane fusion, break-down of transmembrane gradients, to name a few); however, plants can use sugars, synthesized during cold acclimation or from hydrolyzed fructan, to resist plasmolysis by increasing osmotic pressure within cells. Minimum cell volume was shown to be a significant contributor to tissue death, but Williams [68] demonstrated that wheat changed its lethal cell volume size by altering membrane properties, which in turn lowered its kill temperature.
A similar protective mechanism for fructan with regard to dehydration stress was proposed because of the relationship of sugars to drought tolerance [69]. It has been suggested that hexose sugars from hydrolyzed fructan could lower the water potential of intracellular liquid and allow continued leaf expansion during periods of drought [70-72].

Role of fructan in subzero acclimation

Freezing wheat at $-3^{\circ} \mathrm{C}$ for several days induced a decrease in fructan concentration along with an increase in simple sugar [73]. The subzero treatment also increased freezing tolerance to levels beyond that achieved when plants were cold acclimated at temperatures above freezing. This increase in freezing tolerance at subzero temperatures (Trunova [73] credits Tumanov with this discovery in 1931) was called "second-phase hardening" in contrast to first-phase hardening (or cold acclimation) that occurs at temperatures just above freezing. Secondphase hardening is now referred to as "subzero acclimation" [62].

Olien [74] proposed a mechanism of freeze injury called adhesion, which is a result of a hydrophilic compound such as a cell wall or membrane competing with ice for liquid water at an interface [75]. As freezing progresses in plants and dehydration causes cells to shrink, adhesions to walls and membranes can cause significant damage to cells that is histologically distinct from desiccation injury. A carbohydrate analysis of winter cereals indicated that fructan hydrolysis and a concomitant increase in hexose sugars during subzero acclimation was more pronounced in rye (the most winter-hardy cereal crop) than it was in barley, and furthermore the increase in sugars was primarily in the apoplast [76]. Olien proposed that hexose sugars from hydrolyzed fructan were released into the liquid interface during freezing in hardy plants. This would increase the chemical potential of the liquid interface, which would induce melting and either prevent or relieve adhesions.

Studies that contradict the relationship of sugar concentrations to freezing tolerance $[45,51,77]$ indicate that the role of sugars and fructan in protection from abiotic stress is complex [78]. While most studies with grasses report positive correlations of fructan with freezing tolerance [79], Hendry [3] calls into question the relationship of fructan with freezing tolerance in 130 species of the less freezing-tolerant Sheffield flora. Pollock et al. [57] report no correlation between freezing and soluble carbohydrate in two Lolium perenne cultivars. Livingston et al. [80] reported that the tolerance of 23 oat genotypes to freezing under controlled conditions was correlated with a low degree of polymerization $(\mathrm{DP})$ in fructan $(\mathrm{DP}<6)$ and not with fructan DP $>6$. However, in wheat, triticale, and several rye 
cultivars, high-DP fructan was more closely correlated with freezing tolerance than low-DP fructan [45].

The relationship of fructan to abiotic stress tolerance is clearly more complicated than originally supposed and is likely related to differences between fructan molecules in size and structure as well as localization [62] within tissue that is vital for survival of the whole plant [61].

\section{Direct protective effects of fructan: membrane stabilization}

\section{Problem of fructan localization}

While several mechanisms to explain the indirect role of fructan as a hexose reserve had been proposed, the localization of fructan exclusively in the vacuole [13, 32, 81] made a direct role in protection of the plasma membrane from freezing somewhat problematic. It did, however, leave open the possibility that fructan may protect the tonoplast from damage. Livingston and Henson [56] studied fructan and its hydrolysis products in crown tissues of oat and confirmed that a mild freeze increased apoplastic hexoses but also somewhat unexpectedly discovered that fructan itself increased in the apoplast beyond levels that could be explained by simple membrane rupture. Fructan was also found in guttated liquid [56] confirming the presence of fructan in the apoplast of cold-acclimated plants. Zuther et al. [82] demonstrated long-distance transport of DP3 fructan via the apoplast (phloem) in potato, albeit this was in a transgenic system that does not occur naturally in potato. Wang and Nobel [83] demonstrated phloem transport of small fructans in leaf tissue of Agave deserti. The presence of fructan in the apoplast supports the hypothesis that fructan directly protects tissues from freezing/dehydration injury, in addition to serving an indirect role as a hexose reserve.

Liposomes as a model system

Many investigations on the protective effects of various solutes have used liposomes as model systems to elucidate the physical details of membrane protection during dehydration induced by freezing or drying. In addition, liposomes are increasingly used to encapsulate active compounds for pharmaceutical or cosmetic use, and complexes of liposomes and DNA (lipoplexes) may be used to deliver DNA for targeted transfection to specific cells in the body. For all these applications to be practical, the active formulations have to be stored and shipped, preferably at ambient temperature in the dry state, adding further interest to understanding the molecular determinants of dry-state stability.
Membrane fusion and sugar glasses

When water is removed from a liposome suspension during drying, all components within the original suspension are progressively concentrated. This is also true for the liposomes, which are brought into close physical contact that can lead to membrane fusion. In most cases, the fusion of liposomes is accompanied by the formation of transient pores in the membranes, leading to the leakage of soluble molecules out of the vesicles [84, 85] and to the formation of larger liposomes or of large multilamellar membrane aggregates [86].

Most sugars form glasses (vitrify) during drying at ambient temperatures (see [87, 88] for reviews). Physically, a glass is a metastable solid. It is spatially homogeneous, but it has no defined long-range structure, such as a crystal lattice [88]. Due to its extremely high viscosity, all processes that require diffusion are slowed down in glasses to the point that under human observation they appear to stop [89]. Vitrification during drying will therefore fix the position of the liposomes in the glassy matrix, so that the close approach of vesicles necessary for fusion is prohibited. Obviously, the effectiveness of this mechanism, especially during long-term storage, depends on the physical stability of the glass. The melting temperature of a sugar glass (glass transition temperature; $T_{\mathrm{g}}$ ) is a convenient and often used measure of glass stability [87]. Raising the temperature above $T_{\mathrm{g}}$ leads to increased fusion and leakage from liposomes [90]. In addition, water is an effective plasticizer of sugar glasses, although the degree of plasticization differs among different di-, oligo-, and polysaccharides [91-93]. Therefore, storage stability of a sample or survival of an organism will depend in a complex manner on time, temperature, and humidity. During the drying process itself, a sugar with a higher $T_{\mathrm{g}}$ will vitrify at a higher water content at a given temperature. Therefore, a higher $T_{\mathrm{g}}$ will be beneficial during drying because it allows vitrification and prevents fusion at an earlier stage of the drying process. Using sugars with increasing $T_{\mathrm{g}}$ results in reduced liposome fusion in the dry state, especially at elevated temperatures [94].

\section{Liposome protection by polysaccharides}

In general, $T_{\mathrm{g}}$ increases with the molecular weight of the solute [95]. Polysaccharides could therefore be expected to be good protectants for liposomes during drying because in the dry state, all polysaccharides that have been investigated in this regard showed high $T_{\mathrm{g}}$ values (fructans $154^{\circ} \mathrm{C}$ [96]; hydroxyethyl starch $(\mathrm{HES})>100^{\circ} \mathrm{C}[93,97]$; dextran $>100^{\circ} \mathrm{C}$ [98]). Therefore, they are expected to be efficient protectants against liposome fusion in the dry state. Such protection has been shown during air-drying for HES [97, 
99], dextran, and fructan [100]. Also, lipoplexes can be protected from fusion and aggregation by high DP fructans and dextrans [101, 102].

Oligosaccharides also protect liposomes from fusion during drying. In general, one would expect better protection against fusion from longer oligosaccharides because of the expected increase in $T_{\mathrm{g}}$. This is true for raffinose family oligosaccharides (RFO) [94, 103] and malto-oligosaccharides up to DP 5 [104, 105], which show increased protection against fusion with increasing DP. However, protection against fusion decreases with DP in the presence of longer-chain malto-oligosaccharides, inulins, and manno-oligosaccharides [104, 105].

On the other hand, $T_{\mathrm{g}}$ increases as expected with DP in all investigated oligosaccharides [91, 92, 96, 103, 105]. As a result, for malto-, manno-, and fructo-oligosaccharides, the expected reduction in fusion with increasing $T_{\mathrm{g}}$ during liposome drying was not observed in all cases. In fact, in the presence of manno-oligosaccharides and inulins, a linear increase in fusion with increasing $T_{\mathrm{g}}$ has recently been reported [105]. These unexpected findings suggest that there must be a certain degree of structural flexibility in sugar glasses that depends on both the chain length of the oligosaccharides and the nature of the monomeric building blocks and/or their linkages and that allows the diffusion of liposomes at least over very short distances. Inhomogeneities in sugar glasses below $T_{\mathrm{g}}$ have indeed been shown by spectroscopic methods [106, 107], but their structural basis is so far unknown. Recent progress in molecular dynamics (MD) simulation of the glassy state [108] may offer the opportunity to understand the atomic interactions contributing to the structural features that determine the ability of a particular oligosaccharide to prevent liposome fusion in the dry, glassy state.

Sugars prevent lipid phase transitions

The removal of water from a liposome suspension leads to the close approach of vesicles, resulting in membrane fusion events as discussed above. Water plays a much more general, essential role in the formation of bilayers from lipids and in membrane stability. The lipid headgroups directly interact with water through $\mathrm{H}$-bonding and thereby ensure spacing of the lipid molecules in the liquid-crystalline state (see [109] for a comprehensive review). During dehydration, the water molecules that help to maintain this spacing between the lipid headgroups are (partially) removed, allowing a closer approach of the lipid molecules. This leads to an increase in van der Waals interactions between the fatty acyl chains and to an increase in the gel to liquid-crystalline phase transition temperature $\left(T_{\mathrm{m}}\right)$ of the membranes by as much as $70^{\circ} \mathrm{C}$ [110]. This elevation of $T_{\mathrm{m}}$ in dry membranes is especially detrimental if the membrane lipids have a subambient $T_{\mathrm{m}}$ under hydrated conditions, as is the case for almost all biological membranes. When $T_{\mathrm{m}}$ increases above the ambient temperature, the lipids will undergo two phase transitions, one from liquid-crystalline to gel phase during drying and one from gel to liquid-crystalline phase during rehydration (see [111, 112] for reviews). These phase transitions result in transient leakage of soluble cell contents through the membrane $[97,113]$. Therefore, in liposomes, damage during drying and rehydration is commonly determined as the leakage of a soluble marker molecule from the interior of the lipid vesicles. This leakage is thought to be due to inhomogeneities in the membrane during the phase transition [114] because of the coexistence of gel- and fluid-phase lipids that results in packing defects and increased permeability [115].

In contrast, when membranes are dried in the presence of sufficiently high amounts of disaccharides, such as trehalose or sucrose, leakage of soluble content from liposomes can be largely prevented [90, 116, 117]. The water-replacement hypothesis suggests that the sugar molecules prevent the close approach of lipids during dehydration through $\mathrm{H}$-bonding interactions between the sugar $\mathrm{OH}$-groups and the lipid headgroups. This prevents the dehydration-induced increase in $T_{\mathrm{m}}$ [111] and consequently phase transitions and solute leakage. Fouriertransform infrared spectroscopy (FTIR) and nuclear magnetic resonance spectroscopy (NMR) have provided evidence for such interactions between disaccharides and phospholipid headgroups, mostly at the level of the $\mathrm{P}=\mathrm{O}$ moiety of phosphatidylcholines (see e.g., [118-120]). However, such H-bonding interactions may be even more effective, but also more specific to particular sugars, in membranes containing glycolipids [121-124]. Evidence from several MD simulation studies indicates that interactions between membrane phospholipids and sugars are not restricted to completely anhydrous systems, but already occur in hydrated membranes at moderate sugar concentrations [125-129]. This may indicate that similar interactions could also contribute to the stabilization of membranes by disaccharides during freezing, where water is only partially removed by ice crystallization and also already at early stages of the drying process. This latter point has been convincingly demonstrated in experiments where liposome samples containing different amounts of sucrose were equilibrated at various relative humidities. Measurements by differential scanning calorimetry (DSC) showed that sucrose reduced the dehydration-induced increase of lipid $T_{\mathrm{m}}$, already at moderately lowered relative air humidities, where the samples still contain an appreciable amount of water [130].

Despite their superior ability to prevent fusion during drying, polysaccharides such as HES and dextran did not 
protect liposomes against leakage [97, 99, 131, 132]. The reason for this is the inability of HES [97, 99, 120, 133] and dextran $[100,133]$ to depress $T_{\mathrm{m}}$ in dry membranes. This has been related to the inability of these polysaccharides to H-bond to the lipid headgroups [97, 99, 116, 120 , 131].

\section{Role of fructan in membrane stabilization}

The class of polysaccharides that has been most thoroughly investigated with regard to their protective effects on liposomes during drying are fructans. Both a plant inulin (from chicory roots) and a bacterial levan (from Bacillus subtilis) can protect liposomes from leakage during freezedrying or air-drying [131, 132]. Chicory inulin is a mixture of polysaccharides with a degree of polymerization (DP) between 10 and 30, corresponding to molecular masses between approximately 1,600 and 5,000 [131]. During freeze-drying, the presence of the chicory inulin in phosphatidylcholine liposome preparations reduces the degree of leakage after rehydration [131]. This protective effect is related to a depression of $T_{\mathrm{m}}$ in the dry membranes compared to liposomes dried without the fructan. By FTIR, it could also be shown that the inulin establishes $\mathrm{H}$-bonds to the lipid $\mathrm{P}=\mathrm{O}$ despite its large size [131]. This indicates that steric factors can be overcome even by large molecules to enable the insertion of at least part of the polysaccharide into the lipid headgroup region. It was shown in the same study that HES was not able to interact with the $\mathrm{P}=\mathrm{O}$ groups in dry membranes or depress $T_{\mathrm{m}}$ under identical experimental conditions. This indicates that inulins have structural properties different from glucans. During slow air-drying, chicory inulin provides no protection to liposomes [131]. This is due to the fact that chicory inulin has a low solubility and therefore precipitates during the slow drying process, while during freeze-drying, the inulin is immobilized during the freezing step. Similarly, high-DP fructans from oat and rye are also not able to prevent leakage or fusion in liposomes during drying [134]. This may also be related to solubility problems. Inulins as well as fructans from oat and rye with a lower DP (below 7 to 10 , depending on the structures), which are more soluble, do not precipitate during air-drying and provide protection to liposomes [104, 132, 134].

The levan isolated from Bacillus subtilis has a DP of about 125 , corresponding to a molecular mass of approximately 25,000 [135]. Although this fructan has a much higher DP than chicory inulin, it also has a much higher solubility. Therefore, it will not precipitate from solution during air-drying and protects liposomes from leakage and fusion [132]. It has been shown by x-ray diffraction measurements that the levan is located between the liposomes in the dry state, thus enabling both encasement in a glassy matrix and direct interactions with the membrane lipids [132]. In contrast to most other polysaccharides, the presence of levan resulted in a depression of $T_{\mathrm{m}}$ and increased mobility of fatty acyl chains in the dry membranes, as determined by FTIR and NMR spectroscopy [132]. NMR measurements also indicated a strong immobilization of the headgroup both at the $\mathrm{P}=\mathrm{O}$ and the choline level in the presence of levan [100] and detailed FTIR analyses provided evidence for limited $\mathrm{H}$-bonding of levan to the lipid $\mathrm{P}=\mathrm{O}$ groups [136].

To gain further insight into the physical mechanisms and structural determinants of membrane protection by fructans, we compared the effects of different structural families of oligosaccharides on liposomes during drying. It had been suggested earlier that oligosaccharides show reduced protection for liposomes during drying, compared to sucrose, and that strongly reduced protective effects can be expected above DP 3 [99, 137]. Our analyses showed that this is true for manno- and malto-oligosaccharides, while inulins and RFO show the opposite behavior, i.e., increased protection with DP [94, 104, 138]. The structurally more complex fructans from oat and rye showed increased protection only up to a DP of about 4 and with higher DP protection decreased again [104]. Interestingly, some of these cereal fructans showed synergistic behavior in mixtures. Collectively, these findings indicate that there must be specific structural features of the oligosaccharides that determine their efficacy as membrane stabilizers during drying.

The protective effects of sugars for liposomes against leakage of their soluble content can at least in part be related to the effects of the protectants on $T_{\mathrm{m}}$ in the dry state $[111,118]$. Inulins (up to DP 5) show no effect of DP on $T_{\mathrm{m}}[104,138]$, the RFO (up to DP 5) lead to a slight increase in $T_{\mathrm{m}}$ with DP [94], while malto-oligosaccharides (up to DP 7) and manno-oligosaccharides (up to DP 6) lead to progressively greater increases in $T_{\mathrm{m}}$ with DP $[104,138]$. The shift in the spectral position of the $\mathrm{P}=\mathrm{O}$ vibration in FTIR spectra, indicating H-bonding between sugar and lipid headgroup shows no effect of DP for inulins, a slight reduction for RFO, but a strong reduction for malto- and manno-oligosaccharides, in general agreement with the $T_{\mathrm{m}}$ data $[94,104,138]$.

Protective function is a result of oligosaccharide structure

These data suggest that specific structural features of the different oligosaccharide families determine their dramatically different abilities to H-bond to lipid headgroups in membranes in the dry state. There are various levels at which the structure of oligosaccharides could differ and thereby influence the interactions with membrane surfaces. 
These could include different degrees of structural flexibility around the glycosidic bonds and differences in exposed hydrophobic surface area that might facilitate interactions with membrane lipids. There is some indication in the literature that structural flexibility may be a crucial factor that distinguishes different oligosaccharide families. Evidence for this hypothesis comes for instance from MD simulations that show large differences in oligosaccharide structure between gas phase and solution, indicating a major influence of $\mathrm{H}$-bonding interactions on oligosaccharide structure [139-141].

The main structural difference between inulins and the other oligosaccharides is that inulins are mainly (except for one terminal glucose unit) oligofructoses composed of structurally rather flexible furanose rings [142, 143], while the others are composed of more rigid pyranose galactose, glucose, or mannose rings. Therefore, the higher flexibility of the furanose ring may counterbalance the negative steric effects of increasing DP in inulins, leading to an independence of inulin-membrane interactions from size. In more rigid oligosaccharides, on the other hand, negative steric effects dominate the size dependence of these interactions.

This leaves open the question why different pyranosebased oligosaccharides behave differently, and the available evidence suggests a significant contribution of linkage type to the structural flexibility of such sugars. Of the pyranose-based oligosaccharides, RFO show the highest degree of interaction with dry lipids [94]. RFO are $1 \rightarrow 6$ linked carbohydrates and this linkage type affords the oligosaccharides additional flexibility compared to $1 \rightarrow 4$ linked oligosaccharides [144]. This is related to the fact that $1 \rightarrow 6$ linkages involve three dihedral angles, while $1 \rightarrow 4$ and $1 \rightarrow 3$ linkages only involve two dihedral angles, contributing different amounts of structural flexibility [145]. This is reflected in the fact that $1 \rightarrow 6$-linked sugars show a strong influence of H-bonding to water molecules on their conformation [141], implying the ability to adapt their conformation also to optimize H-bonding to lipid molecules in the absence of water. The complexity of the structural dynamics of sugars was recently highlighted by an MD study that systematically investigated the dynamic properties of all possible linkage types between two glucose molecules, showing that each resulting disaccharide had distinct flexibility features [146]. Also, differences in the effects of malto- and manno-oligosaccharides may be related to the higher flexibility of the $\alpha$-glycosidic linkage compared to the $\beta$-glycosidic linkage [147]. While the type of glycosidic linkage will certainly have an effect on the mechanical properties of sugars, there are no simple rules to link the two properties. Different $\beta \quad 1 \rightarrow 4$-linked polysaccharides for instance differ in their mechanical properties and bond flexibility between highly rigid (e.g., chitin, cellulose) and highly flexible (e.g., xylan, hyaluronan) [139], indicating that depending on other structural features, the same glycosidic bond can result in opposite mechanical properties for different sugars.

In addition, although they are usually highly soluble in water, sugars nevertheless have hydrophobic properties, determined by the planar, rigid ring structures with a $\mathrm{CH}$ rich hydrophobic plane on one side [148]. This hydrophobicity has been quantified as the ratio of hydrophobic to hydrophilic surface area of the sugar rings, expressed as a hydrophobic index (HI) [149]. There is a close correlation between the $\mathrm{HI}$ of various sugars and their effect on lipid $T_{\mathrm{m}}$ in systems of low water content [150]. This indicates that hydrophobic interactions play an important role in determining the effectiveness of at least simple sugars on membrane behavior at low hydration. A recent NMR study provided additional evidence that the binding of model polyol compounds to phospholipid membranes in the fully hydrated state occurs through hydrophobic interactions [151]. Unfortunately, these studies have so far not been extended to more complex oligo- and polysaccharides. It can, however, be assumed that for such larger molecules, more complex behavior would be observed that would be the result of several different properties and structural constraints. This will have to be elucidated if we are to understand the differences in protective properties of different saccharides for membranes during drying or freezing. This seems all the more interesting in the light of an additional array of novel oligosaccharides that have recently been identified in various organisms [152-154] and that have also been hypothesized to be involved in cellular stress tolerance.

\section{Use of transgenics in studying fructan biosynthesis and abiotic stress tolerance}

The expression of genes encoding enzymes of fructan biosynthetic pathways in non-host systems has been applied since the mid 1990s and from the very beginning played an important role in characterizing enzymatic properties of the fructosyltransferases, at least of plant $[18,155]$ and fungal enzymes [156, 157].

The first cloned genes encoding fructosyltransferases were of bacterial origin. They are levansucrase genes from e.g., Bacillus subtilis [158], Zymomonas mobilis [159] and Erwinia amylovora [160] (Table 2) as well as an inulinsucrase from Streptococcus mutans [161]. All four genes and homologs from other bacterial species (reviewed in [162]) were the first used to generate transgenic plants that produced fructans. Most of these attempts aimed at increased carbohydrate deposition or the production of commercially interesting raw materials. The Bacillus sacB 
Table 2 Heterologous expression experiments using fructosyltransferase genes mentioned in this review. Genes of bacterial, plant, and fungal origin are grouped, and expression studies are sorted by date of publication

\begin{tabular}{|c|c|c|c|c|}
\hline Origin & Target & Transformation & Note & References \\
\hline \multicolumn{5}{|l|}{ Bacterial enzymes } \\
\hline Bacillus subtilis & Escherichia coli & Plasmid vector & SacB gene & {$[158]$} \\
\hline Zymomonas mobilis & Escherichia coli & Plasmid vector & LevU gene & [159] \\
\hline Bacillus subtilis & Nicotiana tabacum & Genomic integration & Enhanced stress tolerance & [78] \\
\hline Bacillus amyloliquefaciens & $\begin{array}{l}\text { Nicotiana tabacum } \\
\text { Solanum tuberosum }\end{array}$ & Genomic integration & Deleterious & [164] \\
\hline Zymomonas mobilis & Nicotiana tabacum & Genomic integration & Enhanced stress tolerance & {$[163]$} \\
\hline $\begin{array}{l}\text { Bacillus subtilis } \\
\text { Plant enzymes }\end{array}$ & Nicotiana tabacum & Genomic integration & Enhanced stress tolerance & [166] \\
\hline Hordeum vulgare & Nicotiana plumbagenifolia & Transient & & {$[18]$} \\
\hline Cynara scolymus & Solanum tuberosum & Genomic integration & 1-SST gene & {$[15]$} \\
\hline Allium сера & Nicotiana plumbagenifolia & Genomic integration & 1-SST gene & {$[170]$} \\
\hline Hordeum vulgare & Pichia pastoris & Genomic integration & 6-SFT & [172] \\
\hline Cynara scolymus & Nicotiana tabacum & Transient & 1-FFT & {$[16]$} \\
\hline Heliantus tuberosus & Petunia hybrida & Genomic integration & $\begin{array}{l}\text { 1-SST gene } \\
\text { 1-FFT gene }\end{array}$ & {$[17]$} \\
\hline Heliantus tuberosus & Beta vulgaris & Genomic integration & 1-SST & {$[184]$} \\
\hline Cynara scolymus & Solanum tuberosum & Genomic integration & $\begin{array}{l}\text { 1-SST gene } \\
\text { 1-FFT gene }\end{array}$ & {$[171]$} \\
\hline Festuca arundinacea & $\begin{array}{l}\text { Pichia pastoris } \\
\text { Nicotiana tabacum }\end{array}$ & $\begin{array}{l}\text { Genomic inegration } \\
\text { Transient }\end{array}$ & 1-SST & {$[173]$} \\
\hline Allium сера & Beta vulgaris & Genomic integration & $\begin{array}{l}\text { 1-SST } \\
\text { 6G-FFT }\end{array}$ & [182] \\
\hline Triticum aestivum & Lolium perenne & Genomic integration & $\begin{array}{l}\text { 1-SST } \\
6-\mathrm{SFT}\end{array}$ & [196] \\
\hline Viguiera discolor & Pichia pastoris & Genomic integration & 1-FFT & [176] \\
\hline Asparagus officinalis & Pichia pastoris & Genomic integration & 6G-FFT gene & {$[177]$} \\
\hline Triticum aestivum & Pichia pastoris & Genomic integration & 6-FEH & {$[37]$} \\
\hline Echinops ritro & Pichia pastoris & Genomic integration & 1-FFT & {$[178]$} \\
\hline Lolium perenne & Pichia pastoris & Genomic integration & 6G-FFT/1-FFT & [179] \\
\hline Agave tequilana & Pichia pastoris & Genomic integration & $1-\mathrm{SST}$ & [180] \\
\hline Heliantus tuberosus & $\begin{array}{l}\text { Solanum tuberosum } \\
\text { Zea mays }\end{array}$ & Genomic integration & $\begin{array}{l}1-\mathrm{SST} \\
1-\mathrm{FFT}\end{array}$ & {$[185]$} \\
\hline Lactuca sativa & Nicotiana tabacum & Genomic integration & 1-SST & [198] \\
\hline Triticum aestivum & Oryza sativa & Genomic integration & $\begin{array}{l}\text { 1-SST } \\
\text { 6-SFT }\end{array}$ & [199] \\
\hline \multicolumn{5}{|l|}{ Fungal enzymes } \\
\hline Aspergillus foetidus & Saccharomyces cerevisiae & Plasmid vector & & [156] \\
\hline Aspergillus sydowi & $\begin{array}{l}\text { Escherichia coli, Saccharomyces cervisiae } \\
\text { Solanum tuberosum }\end{array}$ & $\begin{array}{l}\text { Plasmid vector } \\
\text { Genomic integration }\end{array}$ & Deleterious & [157] \\
\hline
\end{tabular}

gene and the Zymomonas levU gene expression in tobacco $[78,163]$ were used to study the effects of fructan accumulation on abiotic stress tolerance.

In many cases, adverse effects of transgene expression on host metabolism or development, such as growth retardation, necrotic lesions, or sterility, were reported (e.g., [164]). This, as well as low concentrations of bacterial fructans, raised concerns about the physiological significance of these effects on stress tolerance [162, 165]. Nevertheless, in 2002 Konstantinova and colleagues [166] field-tested transgenic tobacco plants expressing the Bacillus subtilis sacB gene and demonstrated higher freezing tolerance under a controlled environment as well as under field conditions. Although the amount of fructan accumulating in transgenic lines was not 
determined, an increase after cold treatment was reported that probably resulted from accumulation of the substrate sucrose during the cold treatment, a response observed in many plant species. When transgenic tobacco plants were analyzed for oxidative damage at chilling and subzero temperatures, malondialdehyde levels had been lowered, indicating reduced lipid peroxidation [167]. Although interactions of fructans with lipids are well established (see above), no mechanism of protection against peroxidation has been described, and thus the observed effect may argue for secondary effects of sacB gene expression. Elevated hydrogen peroxide levels reported for sacB transgenics may be indicative, since hydrogen peroxide can stimulate abiotic as well as biotic stress responses in plants $[168,169]$.

When plant genes encoding fructosyltransferases became available $[15,18,170]$, they were used in plant transformation to study enzyme properties because they could not be functionally expressed in prokaryotic systems. Using plant hosts that did not normally synthesize fructans, it was shown that the sucrose-dependent fructosyltransferase 1-SST produces not only the trisaccharide 1-kestose but also higher homologs in planta [17, 171]. By expression in potato, Hellwege and colleagues [171] confirmed that to synthesize inulin only two enzymes, 1-SST and 1-FFT, are needed as hypothesized by Edelman and Jefford in 1968 [13].

The methylotrophic yeast Pichia pastoris turned out to be a more convenient system for rapid expression of plant fructosyltransferase genes, as it allows production of the enzymes as secreted proteins [172, 173]. Expression of the 1-SST gene from barley and the 6-SFT gene from tall fescue revealed that enzyme specificity is determined by an $\mathrm{N}$-terminal large subunit of the protein [174] and that transferase and hydrolytic activity can be separated [175]. For the chain-elongating enzyme of dicot plants, 1-FFT, Van den Ende and co-workers found that differential substrate specificities of enzymes from various plant species are responsible for the differing fructan patterns that occur in nature [176], thus confirming earlier studies using plant protoplasts as expression systems [16].

In some cases, abnormal activities of fructosyltransferases expressed in Pichia have been reported. For example, a barley 6-SFT had additional 1-SST activity, which was not found for the enzyme isolated from its natural source [172]. Whether this difference is due to secretion of the protein in Pichia is not clear. Nevertheless, the system allows rapid identification of fructosyltransferase activities and is therefore frequently used for cloning fructosyltransferase genes [37, 177-180].

Transgenics and human consumption of fructan

Because inulin and other oligofructoses are health-promoting food ingredients [181], strategies for developing plant production systems [182-184] or fructan-enriched food and feed [185] have been evaluated. Expression of fructosyltransferase genes in nonfructan plants generally yielded only low amounts of fructan with highest levels of about $7 \mathrm{mg} / \mathrm{g}$ tissue in potato [171] and $41 \mathrm{mg} / \mathrm{g}$ tissue in a high-sucrose maize cultivar [185]. The only exception is sugar beet, in which more than $90 \%$ of the storage sucrose was converted into oligofructose upon expression of the 1SST gene from Jerusalem artichoke [183]. Combined expression of 1-SST and 6G-FFT, a transfructosylating activity from onion, produced a $50 \%$ conversion rate, and in this case, the total carbohydrate yield was not reduced [184]. Stoop and colleagues [185] demonstrated that sucrose availability limits fructan synthesis in most nonfructan plants. However, why similar sucrose levels support high-level fructan accumulation in chicory [186] but not in potato has not been resolved. A possible explanation for the difference between fructan and nonfructan plants could be the presence of a vacuolar invertase activity in the latter that could interfere with fructan accumulation [162]. Negative correlation of invertase gene expression and fructan accumulation was demonstrated in wheat [187]. Invertase activity is also low in growing potato tubers [188], but the amount of fructan that accumulates in tubers is only about $5 \%$ of the amount of starch and far below the fructan content of chicory [171].

Despite these difficulties in transgenic fructan production, studies evaluating quality and safety aspects of possible products have been initiated in recent years. Speculations about specific risks of transgenic nutrients have raised the question of "substantial equivalence" of transgenic and conventional foods, and metabolic fingerprinting methods using mass spectroscopic methods were introduced to test applicability of this concept for safety assessment [189]. Suitability of the concept of substantial equivalence is questionable because possible side effects of transgene expression may depend on experimental conditions. For inulin-producing potato plants, reduced accumulation of the amino acid proline has been observed only under waterdeficit conditions [190]. Whether this has to be regarded as an unspecific effect or a balancing response of plant cells that contain high amounts of soluble sugars as osmolytes is an interesting question to plant physiologists. Regarding substantial equivalence, it poses the question of which differences are security-relevant. An even more important point is that not all plant substances are detectable by fingerprinting methods. Thus, combinations of the so-called unbiased screening techniques and case-specific analyses addressing toxins, e.g., glycoalkaloids in potato, are currently recommended for safety assessment [191].

In addition to safety, nutritional aspects have been explored. Although it was demonstrated that addition of inulin or oligofructoses to pet feed and livestock diet has 
beneficial effects on health status and growth performance [192], silage from transgenic potatoes synthesizing inulin caused reduced daily liveweight gains, probably because of a lower starch content [193]. However, positive effects on gut microflora were not investigated, making it impossible to draw final conclusions on the utility of transgenic food and feed.

The use of transgenic approaches to investigate physiological roles of fructan in plants

The physiological advantage of fructan biosynthesis in plants is one of the most active research fields applying transgenic fructan production. Although more than 40,000 plant species produce fructans, a selective advantage for fructan still remains unclear. These questions are now being addressed using expression of fructosyltransferases in nonfructan as well as in naturally fructan-synthesizing plants.

The genes wtf2 and wtfl, encoding 1-SST and 6-SFT, respectively, were identified from wheat based on sequence homology and heterologous expression in Pichia [194]. These genes were subsequently transferred into perennial ryegrass (Lolium perenne) either alone or in combination. Perennial ryegrass naturally produces fructans mainly of the 6G kestotriose (neokestose) and inulin type [195], and accumulation of fructans during autumn is correlated with a gain in winter hardiness. Constitutive expression of each of the wheat fructosyltransferases alone led to 3- to 15-fold increases in total fructan content and caused increased freezing tolerance [196]. Although it is generally assumed that 1-SST and 6-SFT operate jointly to generate the levan series of fructans, combined overexpression of both genes in ryegrass failed to increase fructan production. A likely reason was a co-suppression effect of the two transgenes, which led to reduced fructosyltransferase mRNA level in the plants transgenic for both wheat genes [196].

Freezing tolerance of the transgenic ryegrass was tested under laboratory conditions after a cold acclimation period of 3 weeks at $6^{\circ} \mathrm{C}$ during the day and $2^{\circ} \mathrm{C}$ during the night. Since the change in fructan concentration was not reported, it is not known whether fructan hydrolysis occurred, in which case an indirect role of fructan in freezing tolerance must be assumed. Clearly, additional data are needed for these plants to fully exploit the potential of this system. It would be interesting to study the structural pattern of fructans in ryegrass plants overexpressing 6-SFT. Pavis and co-workers [197] reported that a typical 6-SFT activity may not be present in Lolium perenne, which produces mainly inulin- and neokestose-type fructans. 6-SFT expression would thus establish a new pathway of fructan synthesis. Although no difference in freezing tolerance between 1-SST- and 6-SFT-overexpressing ryegrass plants was obvious from the study of Hisano and colleagues, the system offers the chance to study the influence on freezing tolerance not only of chain length but also of the structure of fructans.

Expression of a 1-SST gene from lettuce (Lactuca sativa) in tobacco significantly reduced electrolyte leakage from

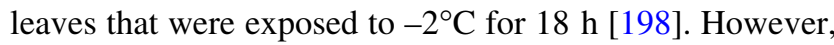
as shown for other nonfructan hosts, fructan contents of transgenic plants were extremely low with $0.04 \mathrm{mg} / \mathrm{g} \mathrm{FW}$ before and $0.1 \mathrm{mg} / \mathrm{g}$ FW after cold acclimation. When comparing the $3-5 \mathrm{mg} / \mathrm{g}$ FW found in wild-type ryegrass and the $40 \mathrm{mg} / \mathrm{g}$ FW obtained in the transgenic plants described above, it seems unlikely that improvement of freezing tolerance in both transgenic plants is caused by a similar mechanism. Lower lipid peroxidation was observed for transgenic tobacco plants expressing bacterial fructosyltransferases. This indicates that expression of plant fructosyltransferases caused an amplified oxidative defense, although this could not be demonstrated at the level of superoxide dismutase (SOD) activity [198]. It will be necessary to analyze in more detail whether increases in protection against lipid peroxidation are specific effects of fructans, or whether the reduced lipid peroxidation in the transgenic tobacco plants indicates that transgene expression led to some nonspecific stress responses.

Relationship of fructan to chilling and drought tolerance

Transgenic rice expressing the $w t f 2$ gene encoding 1-SST accumulated fructo-oligosaccharides at a mean concentration of $16.2 \mathrm{mg} / \mathrm{g}$ FW [199], which is well above the concentration found in ryegrass [197], however, still below that found in barley or oat [9]. Kawakami and colleagues [199] attributed the high transgenic fructan levels to the high sucrose concentrations in rice leaves. Indeed, sucrose concentrations in rice leaves appear about 50-fold higher than in potato or Arabidopsis thaliana, and still 15-fold higher than in potato tubers, which accumulated only one-third of the fructan found in transgenic rice leaves. The strict dependence of fructan accumulation on sucrose concentrations is in agreement with the work of Stoop and colleagues [185], who demonstrated inulin accumulation up to $41 \mathrm{mg} / \mathrm{g}$ kernel in high-sucrose maize. However, the existence of an additional metabolic difference between the monocotyledonous and dicotyledonous host systems used so far for the expression of fructosyltransferases cannot be excluded.

The concentration of soluble sugars in the fructanproducing rice plants was twice as high in leaves and showed no growth retardation or other abnormalities [199]. This increased sugar was a result of higher glucose and fructan concentrations both of which were correlated with improved chilling tolerance [199]. Since glucose and fructan were both 
correlated among each other, except for two lines that expressed the 6-SFT homolog $w t f 1$, it is difficult to assign a specific effect to fructan, especially because, of the latter two lines, only one showed improved chilling tolerance.

One component of chilling stress in rice is water deficit caused by an imbalance of transpiration and water transport from the roots. Thus, any osmolyte can have a positive effect, so a specific role for fructan would not be required. To investigate how fructan may be involved in chilling tolerance the possibility of fructan degradation in the cold should be determined. The vacuolar invertase OsVIN2 of rice shows high fructan exohydrolase activity [42] and is induced at low temperature [200]. A degradation of fructan during abiotic stress treatments has also been found in crown tissue of the naturally fructan-producing grass Festuca novae-zelandiae during prolonged water deficit [201]. Therefore, fructans could act indirectly by providing carbon and energy for the synthesis of other osmo-protectants. Alternatively, fructans could accumulate in the cold or at mild water deficit simply because of high sucrose levels resulting from low respiratory demand in sink organs under stress. The key enzyme of fructan biosynthesis, 1SST, is induced by high sucrose contents in barley [202, 203], and fructan synthesis increases when sucrose accumulates in leaves of grasses [32] and Asteraceae [15]. Thus, clarification of the physiological advantage of fructan biosynthesis is still pending, but transgenic systems are now available to resolve this question.

Open Access This article is distributed under the terms of the Creative Commons Attribution Noncommercial License which permits any noncommercial use, distribution, and reproduction in any medium, provided the original author(s) and source are credited.

\section{References}

1. French AD, Waterhouse AL (1993) Chemical structure and characteristics. In: Suzuki M, Chatterton NJ (eds) Science and technology of fructans. CRC Press, Boca Raton, pp 41-81

2. Hendry GA (1987) The ecological significance of fructan in a contemporary flora. New Phytol 106:201-216

3. Hendry GAF, Wallace RK (1993) The origin distribution and evolutionary significance of fructans. In: Suzuki M, Chatterton NJ (eds) Science and technology of fructans. CRC Press, Boca Raton, pp 119-139

4. Meier H, Reid JSG (1982) Reserve polysaccharides other than starch in higher plants. In: Loewus FA, Tanner W (eds) Encyclopedia of plant physiology, vol 13A. Plant carbohydrates I: intracellular carbohydrates. Springer-Verlag, Berlin, pp 418-471

5. Vijn I, Smeekens S (1999) Fructan: more than a reserve carbohydrate? Plant Physiol 120:351-359

6. Roberfroid MB (2005) Inulin-type fructans: functional food ingredients. CRC Press, Boca Raton, p 392

7. Bancal P, Carpita NC, Gaudillere JP (1992) Differences in fructan accumulated in induced and field-grown wheat plants: an elongation-trimming pathway for their synthesis. New Phytol 120:313-321
8. Shiomi N (1989) Properties of fructosyltransferases involved in the synthesis of fructan in liliaceous plants. J Plant Physiol 134:151-155

9. Livingston DP III, Chatterton NJ, Harrison PA (1993) Structure and quantity of fructan oligomers in oat (Avena spp.). New Phytol 123:725-734

10. Sims IM, Pollock CJ, Horgan R (1992) Structural analysis of oligomeric fructans from excised leaves of Lolium temulentum. Phytochemistry 31:2989-2992

11. Waterhouse AL, Chatterton NJ (1993) Glossary of fructan terms. In: Suzuki M, Chatterton NJ (eds) Science and technology of fructans. CRC Press, Boca Raton, pp 1-7

12. Pollock CJ (1984) Sucrose accumulation and the initiation of fructan biosynthesis in Lolium temultentum L. New Phytol 96:527-534

13. Edelman J, Jefford TG (1968) The mechanism of fructosan metabolism in higher plants as exemplified in Helianthus tuberosus. New Phytol 67:517-531

14. Darbyshire B, Henry RJ (1981) Differences in fructan content and synthesis in some Allium species. New Phytol 87:249-256

15. Hellwege EM, Gritscher D, Willmitzer L, Heyer AG (1997) Transgenic potato tubers accumulate high levels of 1-kestose and nystose: functional identification of a sucrose sucrose 1fructosyltransferase of artichoke (Cynara scolymus) blossom discs. Plant J 12:1057-1065

16. Hellwege EM, Raap M, Gritscher D, Willmitzer L, Heyer AG (1998) Differences in chain-length distribution of inulin from Cynara scolymus and Helianthus tuberosus are reflected in a transient plant expression system using the respective 1-FFT cDNAs. FEBS Lett 427:25-28

17. Van der Meer IM, Koops AJ, Hakkert JC, van Tunen A (1998) Cloning of fructan biosynthesis pathways of Jerusalem artichoke. Plant J 15:489-500

18. Sprenger N, Bortlik K, Brandt A, Boller T, Wiemken A (1995) Purification, cloning and functional expression of sucrose:fruc$\tan$ 6-fructosyltransferase, a key enzyme of fructan synthesis in barley. Proc Natl Acad Sci USA 92:11652-11656

19. Vijn I, van Dijken A, Sprenger N, Dun K, van Weisbeek P, Wiemken A, Smeekens SCM (1997) Fructan of the inulin neoseries is synthesized in transgenic chicory plants (Cichorium intybus L.) harbouring onion (Allium cepa L.) fructan:fructan 6fructosyltansferase. Plant J 11:387-398

20. St John JA, Sims IM, Bonnet GD, Simpson RJ (1997) Identification of products formed by a fructan:fructan fructosyltransferase activity from Lolium rigidum. New Phytol 135:249-257

21. Van den Ende W, Van Laere A (1996) De-novo synthesis of fructans from sucrose in vitro by a combination of two purified enzymes (sucrose:sucrose 1-fructosyl transferase and fructan:fructan 1-fructosyl transferase) from chicory roots (Cichorium intybus L.). Planta 200:335-342

22. Gallagher JA, Cairns AJ, Pollock CJ (2004) Cloning and characterization of a putative fructosyltransferase and two putative invertase genes from the temperate grass Lolium temulentum L. J Exp Bot 55:557-569

23. Archibold HK (1940) Fructosans in the monocotyledons. A review. New Phytol 39:185-219

24. Eagles CF (1967) Variation in the soluble carbohydrate content of climatic races of Dactylis glomerata (cocksfoot) at different temperatures. Ann Bot 31:645-651

25. Pollock CJ (1979) Seasonal patterns of fructan metabolism in forage grasses. New Phytol 83:9-15

26. Westhafer MA, Law JT Jr, Duff DT (1982) Carbohydrate quantification and relationships with $\mathrm{N}$ nutrition in cool-season turfgrasses. Agron J 74:270-274

27. Chatterton NJ, Harrison PA, Bennett JH, Asay KH (1989) Carbohydrate partitioning in 185 accessions of Gramineae 
grown under warm and cold environments. J Plant Physiol 134:169-179

28. Pontis HG, Del Campillo E (1985) Fructans. In: Dixon RA (ed) Biochemistry of storage carbohydrates in green plants. Academic Press, London, pp 205-227

29. Trunova TL (1963) The significance of different forms of sugars in increasing the frost resistance of the coleoptiles of winter cereals. Fiziol Rast 10:495-499

30. Pollock CJ, Cairns AJ (1991) Fructan metabolism in grasses and cereals. Ann Rev Plant Physiol Plant Mol Biol 42:77-101

31. Waite R, Boyd J (1953) The water-soluble carbohydrates of grasses. I. Changes occurring during the normal life-cycle. J Sci Food Agric 4:197-204

32. Wagner W, Keller F, Wiemken A (1983) Fructan metabolism in cereals: induction in leaves and compartmentation in protoplasts and vacuoles. J Plant Physiol 112:359-372

33. Pollock CJ (1986) Environmental effects on sucrose and fructan metabolism. In: Randall DD, Miles CD, Nelson CJ, Blevins DG, Miernyk JA (eds) Current topics in plant biochemistry and physiology, vol 5. University of Missouri Press, Columbia, pp $32-46$

34. Pollock CJ, Chatterton NJ (1988) Fructans. In: Stumpf W, Conn PM, Preiss J (eds) The biochemistry of plants, vol 14. Academic Press, New York, pp 109-140

35. Van den Ende W, Clerens S, Vergauwen R, Van Riet L, Van Laere A, Yoshida M, Kawakami M (2003) Fructan 1-exohydrolases. $\beta(2,1)$ trimmers during graminan biosynthesis in stems of wheat? Purification, characterization, mass mapping and cloning of two fructan 1-exohydrolase isoforms. Plant Physiol 131:621-631

36. Henson CA, Livingston DP III (1998) Characterization of a fructan exohydrolase purified from barley stems that hydrolyzes multiple fructofuranosidic linkages. Plant Physiol Biochem 36:715-720

37. Van Riet L, Nagaraj V, Van den Ende W, Clerens S, Wiemken A, Van Laere A (2005) Purification, cloning and functional characterization of a fructan 6-exohydrolase from wheat (Triticum aestivum L.). J Exp Bot 57:213-223

38. Chalmers J, Lidgett A, Cummings N, Cao Y, Forster J, Spangenberg G (2005) Molecular genetics of fructan metabolism in perennial ryegrass. Plant Biotechnol J 3:459-474

39. Van den Ende W, Yoshida M, Clerens S, Vergauwen R, Kawakami A (2005) Cloning, characterization and functional analysis of novel 6-kestose exohydrolases (6-KEHs) from wheat (Triticum aestivum L.). New Phytol 166:917-932

40. Lothier J, Lasseur B, Le Roy K, Van Laere A, PascalePrud'homme M, Barre P, Van den Ende W, Morvan-Bertrand A (2007) Cloning, gene mapping, and functional analysis of a fructan 1-exohydrolase (1-FEH) from Lolium perenne implicated in fructan synthesis rather than in fructan mobilization. $\mathbf{J}$ Exp Bot 58:1969-1983

41. Le Roy K, Lammens W, Verhaest M, De Coninck B, Rabijns A, Van Laere A, Van den Ende W (2007) Unraveling the difference between invertases and fructan exohydrolases: a single amino acid (Asp-239) substitution transforms Arabidopsis cell wall invertase1 into a fructan 1-exohydrolase. Plant Physiol 145:616-625

42. Ji XM, Van den Ende W, Schroeven L, Clerens S, Geuten K, Cheng SH, Bennett J (2007) The rice genome encodes two vacuolar invertases with fructan exohydrolase activity but lacks the related fructan biosynthesis genes of the Pooideae. New Phytol 173:50-62

43. Verhaest M, Lammens W, Le Roy K, De Ranter CJ, Van Laere A, Rabijns A, Van den Ende W (2007) Insights into the fine architecture of the active site of chicory fructan 1-exohydrolase: 1-kestose as substrate vs sucrose as inhibitor. New Phytol 174:90-100
44. Babenko VI, Gevorkyan AM (1967) Accumulation of oligosaccharides and their significance in the low-temperature hardening of cereal grains. Fiziol Rast 14:727-736

45. Suzuki M, Nass HG (1988) Fructan in winter wheat, triticale and fall rye cultivars of varying cold hardiness. Can J Bot 66:17231728

46. Pontis HG (1989) Fructans and cold stress. J Plant Physiol 134:148-150

47. Levitt J (1980) (ed) Responses of plants to environmental stress, vol. 1, 2nd ed. Academic Press, New York

48. Cloutier Y, Siminovitch D (1982) Correlation between cold- and drought-induced frost hardiness in winter wheat and rye varieties. Plant Physiol 69:256-258

49. Meryman HT (1966) The relationship between dehydration and freezing injury in the human erythrocyte. In: Asahina E (ed) Cellular injury and resistance in freezing organisms, vol 2. Proceedings of the international conference on low temperature science. Bunyeido, Sapporo, Japan, pp 231-244

50. Newton R (1923) Colloidal properties of winter wheat plants in relation to frost resistance. J Agric Sci 14:177-191

51. Levitt J, Scarth GW (1936) Frost-hardening studies with living cells 1 . Osmotic and bound water changes in relation to frost resistance and the seasonal cycle. Can J Res 8:267-284

52. Levitt J (1959) Effects of artificial increases in sugar content on frost hardiness. Plant Physiol 34:401-402

53. Sakai A (1960) Relation of sugar content to frost-hardiness in plants. Nature 185:698-699

54. Englmaier P (1987) Carbohydrate metabolism of salt-tolerant fructan grasses as exemplified with Puccinellia peisonis. Biochem Physiol Pflanzen 182:165-182

55. Johansson NO (1970) Ice formation and frost hardiness in some agricultural plants. Contrib Natl Swed Inst Plant Protect 14:365-382

56. Livingston DP III, Henson CA (1998) Apoplastic sugars, fructans, fructan exohydrolase and invertase in winter oat: responses to second-phase cold hardening. Plant Physiol 116:403-408

57. Pollock CJ, Eagles CF, Sims IM (1988) Effect of photoperiod and irradiance changes upon development of freezing tolerance and accumulation of soluble carbohydrate in seedlings of Lolium perenne grown at $2^{\circ} \mathrm{C}$. Ann Bot $62: 95-100$

58. Steponkus PL (1968) The relationship of carbohydrates to cold acclimation of Hedera helix L cv. Thorndale. Physiol Plant 21:777-791

59. Houde M, Saniel C, Lachapelle M, Allard R, Laliberte S, Sarhan F (1995) Immunolocalization of freezing-tolerance-associated proteins in the cytoplasm and nucleoplasm of wheat crown tissues. Plant J 8:583-593

60. Hudson MA, Idle DB (1962) The formation of ice in plant tissues. Planta 57:718-730

61. Livingston DP III, Tallury SP, Premakumar R, Owens S, Olien CR (2005) Changes in the histology of cold hardened oat crowns during recovery from freezing. Crop Sci 45:1545-1558

62. Livingston DP III, Premakumar R, Tallury SP (2006) Carbohydrate partitioning between upper and lower regions of the crown in oat and rye during cold acclimation and freezing. Cryobiology 52:200-208

63. Olien CR (1981) Analysis of midwinter freezing stress. In: Olien CR, Smith MN (eds) Analysis and improvement of plant cold hardiness. CRC Press, Boca Raton, pp 35-58

64. Pearce RS, Houlston CE, Atherton KM, Rixon JE, Harrison P, Hughes MA, Dunn MA (1998) Localization of expression of three cold-induced genes, blt101, blt4.9, and blt 14 in different tissues of the crown and developing leaves of cold-acclimated cultivated barley. Plant Physiol 117:787-795

65. Shibata S, Shimada T (1986) Anatomical observation of the development of freezing injury in orchardgrass crown. J Japan Grassl Sci 32:197-204 
66. Tanino KK, McKersie BD (1985) Injury within the crown of winter wheat seedlings after freezing and icing stress. Can J Bot 63:432-435

67. Canny MJ (1995) Apoplastic water and solute movement: new rules for an old space. Annu Rev Plant Physiol Plant Mol Biol $46: 215-236$

68. Williams RJ (1980) Frost desiccation: an osmotic model. In: Olien CR, Smith MN (eds) Analysis and improvement of plant cold hardiness. CRC Press, Boca Raton, pp 89-115

69. Santarius KA (1973) The protective effect of sugars on chloroplast membranes during temperature and water stress and its relationship to frost desiccation and heat resistance. Planta 113:105-114

70. Darbyshire B, Henry RJ (1978) The distribution of fructans in onions. New Phytol 81:29-34

71. Spollen WG, Nelson CJ (1994) Response of fructan to water deficit in growing leaves of tall fescue. Plant Physiol 106:329336

72. Pollock CJ (1984) Physiology and metabolism of sucrosylfructans. In: Lewis DH (ed) Storage carbohydrates in vascular plants. Cambridge University Press, Campbridge, pp 97-113

73. Trunova TL (1965) Light and temperature systems in the hardening of winter wheat and the significance of oligosaccharides for frost resistance. Fiziol Rast 12:70-77

74. Olien CR (1977) Ice adhesions in relation to freeze stress. Plant Physiol 60:499-503

75. Olien CR, Livingston DP III (2006) A thermodynamic view of interfacial water. Thermochim Acta 451:9-13

76. Olien CR, Lester GE (1985) Freeze-induced changes in soluble carbohydrates of rye. Crop Sci 25:288-290

77. Green DG (1983) Soluble sugar changes occurring during cold hardening of spring wheat fall rye and alfalfa. Can J Plant Sci 63:415-420

78. Pilon-Smits EAH, Ebskamp MJM, Paul MJ, Jeuken MJW, Weisbeek PJ, Smeekens SCM (1995) Improved performance of transgenic fructan-accumulating tobacco under drought stress. Plant Physiol 107:125-130

79. Yukawa T, Watanabe Y (1991) Studies on fructan accumulation in wheat (Triticum aestivum L.). Jpn J Crop Sci 60:385-391

80. Livingston DP III, Elwinger GF, Weaver JC (1992) Fructan and sugars in 273 oat (Avena spp.) accessions. Crop Sci 33:525-529

81. Wiemken A, Frehner M, Keller F, Wagner W (1986) Fructan metabolism, enzymology and compartmentation. In: Randall DD, Miles CD, Nelson CJ, Blevins DG, Miernyk JA (eds) Current topics in plant biochemistry and physiology, vol. 5. University of Missouri Press, Columbia, pp 17-37

82. Zuther E, Kwart M, Willmitzer L, Heyer AG (2004) Expression of a yeast-derived invertase in companion cells results in longdistance transport of a trisaccharide in an apoplastic loader and influences sucrose transport. Planta 218:766

83. Wang N, Nobel PS (1998) Phloem transport of fructans in the crassulacean acid metabolism species Agave deserti. Plant Physiol 116:709-714

84. Frolov VA, Dunina-Barkovskaya AY, Samsonov AV, Zimmerberg J (2003) Membrane permeability changes at early stages of Influenza hemagglutinin-mediated fusion. Biophys $\mathbf{J}$ 85:1725-1733

85. Müller M, Katsov K, Schick M (2003) A new mechanism of model membrane fusion determined from Monte Carlo simulation. Biophys J 85:1611-1623

86. Crowe JH, Crowe LM, Carpenter JF, Aurell Wistrom C (1987) Stabilization of dry phospholipid bilayers and proteins by sugars. Biochem J 242:1-10

87. Buitink J, Leprince O (2004) Glass formation in plant anhydrobiotes: survival in the dry state. Cryobiology 48:215-228
88. Crowe JH, Carpenter JF, Crowe LM (1998) The role of vitrification in anhydrobiosis. Annu Rev Physiol 60:73-103

89. Sun WQ, Leopold AC (1997) Cytoplasmic vitrification of anhydrobiotic organisms. Comp Biochem Physiol 117A:327-333

90. Sun WQ, Leopold AC, Crowe LM, Crowe JH (1996) Stability of dry liposomes in sugar glasses. Biophys J 70:1769-1776

91. Orford PD, Parker R, Ring SG, Smith AC (1989) Effect of water as a diluent on the glass transition behaviour of malto-oligosaccharides, amylose and amylopectin. Int J Biol Macromol 11:91-96

92. Schaller-Povolny LA, Smith DE, Labuza TP (2000) Effect of water content and molecular weight on the moisture isotherms and glass transition properties of inulin. Int J Food Prop 3:173192

93. Sun WQ, Wagner CT, Connor J (2004) The glass transition behaviors of hydroxyethyl starch solutions. Cell Preserv Technol 2:55-65

94. Hincha DK, Zuther E, Heyer AG (2003) The preservation of liposomes by raffinose family oligosaccharides during drying is mediated by effects on fusion and lipid phase transitions. Biochim Biophys Acta 1612:172-177

95. Levine H, Slade L (1988) Principles of "cryostabilization" technology from structure/property relationships of carbohydrate/water systems-a review. CryoLetters 9:21-63

96. Hinrichs WLJ, Prinsen MG, Frijlink HW (2001) Inulin glasses for the stabilization of therapeutic proteins. Int $\mathrm{J}$ Pharm 215:163-174

97. Crowe JH, Oliver AE, Hoekstra FA, Crowe LM (1997) Stabilization of dry membranes by mixtures of hydroxyethyl starch and glucose: the role of vitrification. Cryobiology 35:20-30

98. Koster KL, Lei YP, Anderson M, Martin S, Bryant G (2000) Effects of vitrified and nonvitrified sugars on phosphatidylcholine fluid-to-gel phase transitions. Biophys J 78:1932-1946

99. Crowe JH, Hoekstra FA, Nguyen KHN, Crowe LM (1996) Is vitrification involved in depression of the phase transition temperature in dry phospholipids? Biochim Biophys Acta 1280:187-196

100. Vereyken IJ, Chupin V, Islamov A, Kuklin A, Hincha DK, de Kruijff B (2003) The effect of fructan on the phospholipid organization in the dry state. Biophys J 85:3058-3065

101. Hinrichs WLJ, Mancenido FA, Sanders NN, Braeckmans K, de Smedt SC, Demeester J, Frijlink HW (2006) The choice of a suitable oligosaccharide to prevent aggregation of PEGylated nanoparticles during freeze thawing and freeze drying. Int $\mathbf{J}$ Pharm 311:237-244

102. Hinrichs WLJ, Sanders NN, de Smedt SC, Demeester J, Frijlink HW (2005) Inulin is a promising cryo- and lyoprotectant for PEGylated lipoplexes. J Controlled Release 103:465-479

103. Buitink J, van den Dries IJ, Hoekstra FA, Alberda M, Hemminga MA (2000) High critical temperature above $T_{\mathrm{g}}$ may contribute to the stability of biological systems. Biophys $\mathrm{J}$ 79:1119-1128

104. Hincha DK, Zuther E, Hellwege EM, Heyer AG (2002) Specific effects of fructo- and gluco-oligosaccharides in the preservation of liposomes during drying. Glycobiology 12:103-110

105. Hincha DK, Rennecke P, Oliver AE (2008) Protection of liposomes against fusion during drying by oligosaccharides is not predicted by the calorimetric glass transition temperatures of the dry sugars. Eur Biophys J 37:503-508

106. Shirke S, Ludescher RD (2005) Dynamic site heterogeneity in amorphous maltose and maltitol from spectral heterogeneity in erythrosin B phosphorescence. Carbohydr Res 340:2661-2669

107. Shirke S, Ludescher RD (2005) Molecular mobility and the glass transition in amorphous glucose, maltose, and maltotriose. Carbohydr Res 340:2654-2660 
108. Li D-X, Liu B-L, Liu Y, Chen C-I (2008) Predict the glass transition temperature of glycerol-water binary cryoprotectant by molecular dynamics simulation. Cryobiology 56:114-119

109. Milhaud J (2004) New insights into water-phospholipid model membrane interactions. Biochim Biophys Acta 1663:19-51

110. Crowe JH, Hoekstra FA, Crowe LM (1992) Anhydrobiosis. Annu Rev Physiol 54:579-599

111. Oliver AE, Crowe LM, Crowe JH (1998) Methods for dehydration tolerance: depression of the phase transition temperature in dry membranes and carbohydrate vitrification. Seed Sci Res 8:211-221

112. Oliver AE, Leprince O, Wolkers WF, Hincha DK, Heyer AG, Crowe JH (2001) Non-disaccharide-based mechanisms of protection during drying. Cryobiology 43:151-167

113. Leslie SB, Teter SA, Crowe LM, Crowe JH (1994) Trehalose lowers membrane phase transitions in dry yeast cells. Biochim Biophys Acta 1192:7-13

114. Hays LM, Crowe JH, Wolkers W, Rudenko S (2001) Factors affecting leakage of trapped solutes from phospholipid vesicles during thermotropic phase transitions. Cryobiology 42:88-102

115. Quinn PJ (1985) A lipid-phase separation model of low-temperature damage to biological membranes. Cryobiology 22:128-146

116. Crowe JH, Leslie SB, Crowe LM (1994) Is vitrification sufficient to preserve liposomes during freeze-drying? Cryobiology 31:355-366

117. Madden TD, Bally MB, Hope MJ, Cullis PR, Schieren HP, Janoff AS (1985) Protection of large unilamellar vesicles by trehalose during dehydration: retention of vesicle content. Biochim Biophys Acta 817:67-74

118. Cacela C, Hincha DK (2006) Low amounts of sucrose are sufficient to depress the phase transition temperature of dry phosphatidylcholine, but not for lyoprotection of liposomes. Biophys J 90:2831-2842

119. Hincha DK, Hagemann M (2004) Stabilization of model membranes during drying by compatible solutes involved in the stress tolerance of plants and microorganisms. Biochem J 383:277-283

120. Tsvetkova NM, Phillips BL, Crowe LM, Crowe JH, Risbud SH (1998) Effect of sugars on headgroup mobility in freeze-dried dipalmitoylphosphatidylcholine bilayers: solid-state 31P NMR and FTIR studies. Biophys J 75:2947-2955

121. Bakaltcheva I, Williams WP, Schmitt JM, Hincha DK (1994) The solute permeability of thylakoid membranes is reduced by low concentrations of trehalose as a co-solute. Biochim Biophys Acta 1189:38-44

122. Christensen D, Kirby D, Foged C, Agger EM, Andersen P, Perry Y, Nielsen HM (2008) $\alpha, \alpha^{\prime}$-trehalose 6, 6'-dibehenate in nonphospholipid-based liposomes enables direct interaction with trehalose, offering stability during freeze-drying. Biochim Biophys Acta 1778:1365-1373

123. Hincha DK (1989) Low concentrations of trehalose protect isolated thylakoids against mechanical freeze-thaw damage. Biochim Biophys Acta 987:231-234

124. Hincha DK (1990) Differential effects of galactose containing saccharides on mechanical freeze-thaw damage to isolated thylakoid membranes. CryoLetters 11:437-444

125. Leekumjorn S, Sum AK (2006) Molecular investigation of the interactions of trehalose with lipid bilayers of DPPC, DPPE and their mixture. Mol Simul 32:219-230

126. Pereira CS, Hünenberger PH (2006) Interactions of the sugars trehalose, maltose and glucose with a phospholipid bilayer: a comparative molecular dynamics study. J Phys Chem B 110:15572-15581

127. Pereira CS, Lins RD, Chandrasekhar I, Freitas LCG, Hünenberger PH (2004) Interaction of the disaccharide trehalose with a phospholipid bilayer: a molecular dynamics study. Biophys J 86:2273-2285
128. Sum A, Faller R, de Pablo J (2003) Molecular simulation study of phospholipid bilayers and insights of the interactions with disaccharides. Biophys J 85:2830-2844

129. Villarreal MA, Diaz SB, Disalvo EA, Montich GG (2004) Molecular dynamics simulation study of the interaction of trehalose with lipid membranes. Langmuir 20:7844-7851

130. Lenne T, Bryant G, Holcomb R, Koster KL (2007) How much solute is needed to inhibit the fluid to gel membrane phase transition at low hydration? Biochim Biophys Acta 1768:1019-1022

131. Hincha DK, Hellwege EM, Heyer AG, Crowe JH (2000) Plant fructans stabilize phosphatidylcholine liposomes during freezedrying. Eur J Biochem 267:535-540

132. Vereyken IJ, Chupin V, Hoekstra FA, Smeekens SCM, de Kruijff B (2003) The effect of fructan on membrane lipid organization and dynamics in the dry state. Biophys J 84:3759-3766

133. Koster KL, Maddocks KJ, Bryant G (2003) Exclusion of maltodextrins from phosphatidylcholine multilayers during dehydration: effects on membrane phase behavior. Eur Biophys J 32:96-105

134. Hincha DK, Livingston DP III, Premakumar R, Zuther E, Obel N, Cacela C, Heyer AG (2007) Fructans from oat and rye: composition and effects on membrane stability during drying. Biochim Biophys Acta 1768:1611-1619

135. Vereyken IJ, Chupin V, Demel RA, Smeekens SCM, de Kruijff B (2001) Fructans insert between the headgroups of phospholipids. Biochim Biophys Acta 1510:307-320

136. Hincha DK, Popova AV, Cacela C (2006) Effects of sugars on the stability of lipid membranes during drying. In: Leitmannova Liu A (ed) Advances in planar lipid bilayers and liposomes. Elsevier, Amsterdam, pp 189-217

137. Suzuki T, Komatsu H, Miyajima K (1996) Effects of glucose and its oligomers on the stability of freeze-dried liposomes. Biochim Biophys Acta 1278:176-182

138. Cacela C, Hincha DK (2006) Monosaccharide composition, chain length and linkage type influence the interactions of oligosaccharides with dry phosphatidylcholine membranes. Biochim Biophys Acta 1758:680-691

139. Almond A, Sheehan JK (2003) Predicting the molecular shape of polysaccharides from dynamic interactions with water. Glycobiology 13:255-264

140. Brady JW, Schmidt RK (1993) The role of hydrogen bonding in carbohydrates: molecular dynamics simulations of maltose in aqueous solution. J Phys Chem 97:958-966

141. Kirschner KN, Woods RJ (2001) Solvent interactions determine carbohydrate conformation. Proc Natl Acad Sci USA 98:1054110545

142. Vereyken IJ, van Kuik JA, Evers TH, Rijken PJ, de Kruijff B (2003) Structural requirements of the fructan-lipid interaction. Biophys J 84:3147-3154

143. Waterhouse AL, Calub TM, French AD (1991) Conformational analysis of 1-kestose by molecular mechanics and by n.m.r. spectroscopy. Carbohydr Res 217:29-42

144. Lee G, Nowak W, Jaroniec J, Zhang Q, Marszalek PE (2004) Molecular dynamics simulations of forced conformational transitions in 1, 6-linked polysaccharides. Biophys J 87:1456-1465

145. Kony D, Damm W, Stoll S, Hünenberger PH (2004) Explicitsolvent molecular dynamics simulations of the $\beta(1 \rightarrow 3)-$ and $\beta(1 \rightarrow 6)$-linked disaccharides $\beta$-laminarabiose and $\beta$-gentiobiose in water. J Phys Chem B 108:5815-5826

146. Pereira CS, Kony D, Baron R, Müller M, van Gusteren WF, Hünenberger PH (2006) Conformational and dynamical properties of disaccharides in water: a molecular dynamics study. Biophys J 90:4337-4344

147. Kacurakova M, Mathlouthi M (1996) FTIR and laser-Raman spectra of oligosaccharides in water: characterization of the glycosidic bond. Carbohydr Res 284:145-157 
148. Yano Y, Tanaka K, Doi Y, Janado M (1988) The polystyrene affinity of methylglucosides, deoxysugars and glucooligosaccharides. J Solut Chem 17:347-358

149. Miyajima K, Machida K, Taga T, Komatsu H, Nakagaki M (1988) Correlation between the hydrophobic nature of monosaccharides and cholates, and their hydrophobic indices. J Chem Soc Faraday Trans 84:2537-2544

150. Nagase H, Ueda H, Nakagaki M (1999) Relationship between hydrophobic index of saccharide and gel-liquid crystal transition temperature of the L- $\alpha$-dipalmitoyl phosphatidylcholine (DPPC)/saccharide/water system. Chem Pharm Bull 47:607-610

151. Fischer D, Geyer A (2005) NMR spectroscopic characterization of the membrane affinity of polyols. Magn Reson Chem 43:893901

152. Fischer D, Geyer A, Loos E (2006) Occurrence of glucosylsucrose [ $\alpha$-D-glucopyranosyl-( $1 \rightarrow 2)-\alpha$-D-glucopyranosyl- $(1 \rightarrow 2)$ $\beta$-D-fructofuranoside] and glucosylated homologues in cyanobacteria. FEBS J 273:137-149

153. Ohta M, Pan YT, Laine RA, Elbein AD (2002) Trehalose-based oligosaccharides isolated from the cytoplasm of Mycobacterium smegmatis. Eur J Biochem 269:3142-3149

154. Wieneke R, Klein S, Geyer A, Loos E (2007) Structural and functional characterization of galactooligosaccharides in Nostoc commune: $\beta$-D-galactofuranosyl-( $1 \rightarrow 6)-\beta$-D- $(1 \rightarrow 6)$-galactofuranosylated homologues. Carbohydr Res 342:2757-2765

155. Ritsema T, Smeekens SCM (2003) Engineering fructan metabolism in plants. J Plant Physiol 160:811-820

156. Rehm J, Willmitzer L, Heyer A (1998) Production of 1-kestose in transgenic yeast expressing a fructosyltransferase from Aspergillus foetidus. J Bact 180:1305-1310

157. Heyer AG, Wendenburg R (2001) Gene cloning and functional characterization by heterologous expression of the fructosyltransferase of Aspergillus sydowi IAM 2544. Appl Environ Microbiol 67:363-370

158. Gay P, Le Coq D, Steinmetz M, Ferrari E, Hoch JA (1983) Cloning structural gene $\mathrm{sacB}$, which codes for exoenzyme levansucrase of Bacillus subtilis: expression of the gene in Escherichia coli. J Bacteriol 153:1424-1431

159. O'Mullan P, Eveleigh DE (1990) Cloning and expression of zymomonas-mobilis levansucrase in Escherichia coli. Abstr Annu Meet Am Soc Microbiol 90:269

160. Geier G, Geider K (1993) Characterization and influence on virulence of the levansucrase gene from the fireblight pathogen Erwinia amylovora. Physiol Mol Plant Pathol 42:387-404

161. Shiroza T, Kuramitsu HK (1988) Sequence analysis of the Streptococcus mutans fructosyltransferase gene and flanking regions. J Bacteriol 170:810-816

162. Cairns AJ (2003) Fructan biosynthesis in transgenic plants. J Exp Bot 54:549-567

163. Park JM, Kwon SY, Song KB, Kwak JW, Lee SB, Nam YW, Shin JS, Park YI, Rhee SK, Paek K-H (1999) Transgenic tobacco plants expressing the bacterial levansucrase gene show enhanced tolerance to osmotic stress. J Microbiol Biotechnol 9:213-218

164. Caimi PG, McCole LM, Klei TM, Hershey HP (1997) Cytosolic expression of the Bacillus amyloliquefaciens SacB protein inhibits tissue development in transgenic tobacco and potato. New Phytol 136:19-28

165. Bohnert HJ, Shen B (1999) Transformation and compatible solutes. Sci Horticult 78:237-260

166. Konstantinova T, Parvanova D, Atanassov A, Djilianov D (2002) Freezing tolerant tobacco, transformed to accumulate osmoprotectants. Plant Sci 163:157-164

167. Parvanova D, Ivanov S, Konstantinova T, Karanov E, Atanassov A, Tsvetkov T, Alexieva V, Djilianov D (2004) Transgenic tobacco plants accumulating osmolytes show reduced oxidative damage under freezing stress. Plant Physiol Biochem 42:57-63
168. Foyer CH, Lopezdelgado H, Dat JF, Scott IM (1997) Hydrogen peroxide- and glutathione-associated mechanisms of acclimatory stress tolerance and signalling [review]. Physiol Plant 100:241-254

169. Suzuki N, Mittler R (2006) Reactive oxygen species and temperature stresses: a delicate balance between signaling and destruction [review]. Physiol Plant 126:45-51

170. Vijn I, van Dijken A, Lüscher M, Bos A, Smeets E, Weisbeek P, Wiemken A, Smeekens S (1998) Cloning of sucrose:sucrose 1fructosyltransferase from onion and the synthesis of structurally defined fructan molecules from sucrose. Plant Physiol 117:15071513

171. Hellwege EM, Czapla S, Jahnke A, Willmitzer L, Heyer AG (2000) Transgenic potato (Solanum tuberosum) tubers synthesize the full spectrum of inulin molecules naturally occurring in globe artichoke (Cynara scolymus) roots. Proc Natl Acad Sci USA 97:8699-8704

172. Hochstrasser U, Lüscher M, De Virgilio C, Boller T, Wiemken A (1998) Expression of functional barley sucrose-fructan 6fructosyltransferase in the methylotrophic yeast Pichia pastoris. FEBS Lett 440:356-360

173. Lüscher M, Hochstrasser U, Vogel G, Aeschbacher R, Galati V, Nelson CJ, Boller T, Wiemken A (2000) Cloning and functional analysis of sucrose: sucrose 1-fructosyltransferase from tall fescue. Plant Physiol 124:1217-1227

174. Altenbach D, Nuesch E, Meyer AD, Boller T, Wiemken A (2004) The large subunit determines catalytic specificity of barley sucrose:fructan 6-fructosyltransferase and fescue sucrose:sucrose 1-fructosyltransferase. FEBS Lett 567:214-218

175. Altenbach D, Nuesch E, Ritsema T, Boller T, Wiemken A (2005) Mutational analysis of the active center of plant fructosyltransferases: festuca 1-SST and barley 6-SFT. FEBS Lett 579:4647-4653

176. Van den Ende W, Van Laere A, Le Roy K, Vergauwen R, Boogaerts D, Figueiredo-Ribeiro RCL, Machado De Carvalho MA (2005) Molecular cloning and characterization of a high DP fructan:fructan 1-fructosyl transferase from Viguiera discolor (Asteraceae) and its heterologous expression in Pichia pastoris. Physiol Plant 125:419-429

177. Ueno K, Onodera S, Kawakami A, Yoshida M, Shiomi N (2005) Molecular characterization and expression of a cDNA encoding fructan: fructan $6(\mathrm{G})$-fructosyltransferase from asparagus (Asparagus officinalis). New Phytol 165:813-824

178. Van den Ende W, Clerens S, Vergauwen R, Boogaerts D, Le Roy K, Arckens L, Van Laere A (2006) Cloning and functional analysis of a high DP fructan:fructan 1-fructosyl transferase from Echinops ritro (Asteraceae): comparison of the native and recombinant enzymes. J Exp Bot 57:775-789

179. Lasseur B, Lothier J, Djoumad A, De Coninck B, Smeekens S, Van Laere A, Morvan-Bertrand A, Van den EW, Prud'Homme MP (2006) Molecular and functional characterization of a cDNA encoding fructan:fructan 6G-fructosyltransferase (6G-FFT)/ fructan:fructan 1-fructosyltransferase (1-FFT) from perennial ryegrass (Lolium perenne L.). J Exp Bot 57:2719-2734

180. Avila-Fernandez A, Olvera-Carranza C, Rudino-Pinera E, Cassab GI, Nieto-Sotelo J, Lopez-Munguia A (2007) Molecular characterization of sucrose:sucrose 1-fructosyltransferase (1SST) from Agave tequilana Weber var azul. Plant Sci 173:478486

181. Roberfroid MB (2007) Inulin-type fructans: functional food ingredients. J Nutr 137:2493S-2502S

182. Weyens G, Ritsema T, van Dun K, Meyer D, Lommel M, Lathouwers J, Rosquin I, Denys P, Tossens A, Nijs M, Turk S, Gerrits N, Bink S, Walraven B, Lefebvre M, Smeekens S (2004) Production of tailor-made fructans in sugar beet by expression of onion fructosyltransferase genes. Plant Biotechnol J 2:321-327 
183. Sevenier R, van der Meer IM, Bino R, Koops AJ (2002) Increased production of nutriments by genetically engineered crops. J Am Coll Nutr 21:199S-204S

184. Sevenier R, Hall RD, Vandermeer IM, Hakkert HC, Vantunen AJ, Koops AJ (1998) High level fructan accumulation in a transgenic sugar beet. Nat Biotechnol 16:843-846

185. Stoop JM, Van Arkel J, Hakkert JC, Tyree C, Caimi PG, Koops AJ (2007) Developmental modulation of inulin accumulation in storage organs of transgenic maize and transgenic potato. Plant Sci 173:172-181

186. Van den Ende W, Mintiens A, Speleers H, Onuoha AA, Van Laere A (1996) The metabolism of fructans in roots of Cichorium intybus during growth, storage and forcing. New Phytol 132:555-563

187. Xue GP, McIntyre CL, Jenkins CLD, Glassop D, van Herwaarden AF, Shorter R (2008) Molecular dissection of variation in carbohydrate metabolism related to water-soluble carbohydrate accumulation in stems of wheat. Plant Physiol 146:441-454

188. Ross HA, Davies HV, Burch LR, Viola R, McRae D (1994) Developmental changes in carbohydrate content and sucrose degrading enzymes in tuberising stolons of potato (Solanum tuberosum). Physiol Plant 90:748-756

189. Catchpole GS, Beckmann M, Enot DP, Mondhe M, Zywicki B, Taylor J, Hardy N, Smith A, King RD, Kell DB, Fiehn O, Draper J (2005) Hierarchical metabolomics demonstrates substantial compositional similarity between genetically modified and conventional potato crops. Proc Natl Acad Sci USA 102:1445814462

190. Knipp G, Honermeier B (2006) Effect of water stress on proline accumulation of genetically modified potatoes (Solanum tuberosum L.) generating fructans. J Plant Physiol 163:392-397

191. Zywicki B, Catchpole G, Draper J, Fiehn O (2005) Comparison of rapid liquid chromatography-electrospray ionization-tandem mass spectrometry methods for determination of glycoalkaloids in transgenic field-grown potatoes. Anal Biochem 336:178-186

192. Flickinger EA, Fahey GC (2002) Pet food and feed applications of inulin, oligofructose and other oligosaccharides. Br J Nutr 87:S297-S300

193. Bohme H, Hommel B, Flachowsky G (2005) Nutritional assessment of silage from transgenic inulin synthesizing potatoes for pigs. J Anim Feed Sci 14:333-336
194. Kawakami A, Yoshida M (2002) Molecular characterization of sucrose:sucrose 1-fructosyltransferase and sucrose:fructan 6fructosyltransferase associated with fructan accumulation in winter wheat during cold hardening. Biosci Biotechnol Biochem 66:2297-2305

195. Pavis N, Chatterton NJ, Harrison PA, Baumgartner S, Praznik W, Boucaud J, Prud'Homme MP (2001) Structure of fructans in roots and leaf tissue of Lolium perenne. New Phytol 150:83-95

196. Hisano H, Kanazawa A, Kawakami A, Yoshida M, Shimamoto Y, Yamada T (2004) Transgenic perennial ryegrass plants expressing wheat fructosyltransferase genes accumulate increased amounts of fructan and acquire increased tolerance on a cellular level to freezing. Plant Sci 167:861-868

197. Pavis N, Boucaud J, Prud'Homme MP (2001) Fructans and fructan-metabolizing enzymes in leaves of Lolium perenne. New Phytol 150:97-109

198. Li HJ, Yang AF, Zhang XC, Gao F, Zhang JR (2007) Improving freezing tolerance of transgenic tobacco expressing-sucrose sucrose 1-fructosyltransferase gene from Lactuca sativa. Plant Cell Tissue Organ Cult 89:37-48

199. Kawakami A, Sato Y, Yoshida M (2008) Genetic engineering of rice capable of synthesizing fructans and enhancing chilling tolerance. J Exp Bot 59:793-802

200. Ji XM, Raveendran M, Oane R, Ismail A, Lafitte R, Bruskiewich R, Cheng SH, Bennett J (2005) Tissue-specific expression and drought responsiveness of cell-wall invertase genes of rice at flowering. Plant Mol Biol 59:945-964

201. Clark GT, Zuther E, Outred HA, McManus MT, Heyer AG (2004) Tissue-specific changes in remobilization of fructan in the xerophytic tussock species Festuca novae-zelandiae in response to a water deficit. Funct Plant Biol 31:377-389

202. Nagaraj VJ, Riedl R, Boller T, Wiemken A, Meyer AD (2001) Light and sugar regulation of the barley sucrose:fructan 6fructosyltransferase promoter. J Plant Physiol 158:1601-1607

203. Nagaraj VJ, Altenbach D, Galati V, Luscher M, Meyer AD, Boller T, Wiemken A (2004) Distinct regulation of sucrose:sucrose-1-fructosyltransferase (1-SST) and sucrose:fructan-6fructosyltransferase (6-SFT), the key enzymes of fructan synthesis in barley leaves: 1-SST as the pacemaker. New Phytol 161:735-748 